\title{
Research Capability, Job Satisfaction, and a Multiple Approach of Competitiveness: A Conceptual Framework for University Kuala Lumpur, Malaysia
}

\author{
Dr. Milad Abdelnabi Salem ${ }^{1}$ \\ Dr. Fekri Shawtari2 \\ Dr. Mohd Farid Shamsudin ${ }^{3}$ \\ Dr. Hafezali Bin Iqbal Hussain4 \\ Dr. Sheikh Muhamad Hizam ${ }^{5}$ \\ ${ }_{1}^{1}$ Senior Lecturer, Business School, University Kuala Lumpur, Malaysia, Correspondence Author, milad@unikl.edu.my \\ 2 Senior Lecturer, Business School, University Kuala Lumpur, Malaysia. Fekri@unikl.edu.my \\ ${ }^{3}$ Senior Lecturer, Business School, University Kuala Lumpur, Malaysia. mfarid@unikl.edu.my \\ 4 Senior Lecturer, Business School, University Kuala Lumpur, Malaysia. hafezali@unikl.edu.my \\ ${ }_{5}^{5}$ Senior Lecturer, Business School, University Kuala Lumpur, Malaysia. sheikhmhizam@unikl.edu.my
}

Doi:10.5901/mjss.2016.v7n1p369

\section{Abstract}

Despite extensive empirical research linking research capability and competitiveness in the context of manufacturing companies, little attention has focused on the service sector, particularly the educational sector. A review of previous related literature reveals no evidence of research that investigated the relationship between the research capabilities of universities and the multidimensional competitiveness approach. Using the knowledge-based view theory, the study assumes that knowledge is a critical source of competitiveness and there is significant relationship between research capabilities and competitiveness. Additionally, it assumes that such a relationship could be indirect through the mediating effect of job satisfaction. The study contributes to the body of knowledge by testing this theory in the educational field. Additionally, the study uses a multidimensional approach to measure the competitiveness instead of using one proxy of outcomes, which has been widely neglected by similar studies.

Keywords: Research capabilities, Job Satisfaction, Porter's Five Competitive Forces Model, Structure Equation Modeling, Resources- Based View.

\section{Introduction}

It is widely accepted that a nation's competitiveness relies on the competitive ability of organisations (Iraldo, Testa, \& Frey, 2009; Porter \& Van der Linde, 1996; Swift \& Zadek, 2002). Organisations strive to make themselves more effective and efficient by utilising as many resources possible to ensure stability and growth in the modern market environment. Such efforts cause corporations to not only focus on financial returns, but to extend their interests to include dimensions of competitiveness (Lankoski, 2000; López-Gamero, Molina-Azorín, \& Claver-Cortés, 2009).

Competitiveness refers to the results of the match between the internal capabilities of the organisation and its external changes (Hart, 1995). Competiveness results from the efficient use of a firm's tangible and intangible assets (Wernerfelt, 1984; 2011). In other words, resources represent the strengths and weaknesses of the organisation (Duncan, Ginter, \& Swayne, 1998).

In the academic field, the competitiveness of universities in most cases relies on their capabilities such as science research capability, which represent the core capability of universities and the main indicator of any powerful university (Liu \& Shi, 2008). Knowledge-based view theory advocates knowledge possessed and practiced by firm members constitutes a firm's primary resource. This view challenges the shareholder value approach (Grant, 1996). Research capability refers to a process of individual and institutional development which leads to higher level of skills and greater ability to perform useful research (Pickstone, Nancarrow, Cooke, Vernon, Mountain, Boyce, \& Campbell, 2008, p. 77). 


\subsection{Background and the issues of study}

A university's capabilities largely determines its competitive advantage (Giménez, \& Martínez, 2006; Liu \& Shi, 2009; Noruzi \& Vargas-Hernández, 2010; Yang, Lin, \& Li, 2010). In the context of universities, such capabilities constitute their tacit knowledge (Audretsch, Hülsbeck, \& Lehmann, 2012; Grant, 1996; Liu \& Shi, 2008; Sveiby, 2001). This background explains the importance for universities to take stock and evaluate and their capabilities for optimal use (Liu \& Shi, 2008).

Naturally, universities focus on developing their research abilities yet this is often not included when seeking to determine and evaluate their competitive capabilities (Boccardelli \& Magnusson, 2006; Helfat \& Peteraf, 2003; Liu \& Shi, 2008; McEvily \& Marcus, 2005; Teece, 2007; Liu \& Shi, 2008; Siegel, Waldman, Atwater \& Link, 2004), and knowledge creation issues (Noruzi \& Vargas-Hernández, 2010). Noruzi and Vargas-Hernández added that there is a need to consider the extent to which scientific research capability in universities contributes in a sufficient way, to its competitive capability. Additionally, reviewing related literature showed that there is a paucity of studies concerning the relationship between science research capability and competitiveness. To fill such gaps, the current study evaluates the science research capability of University Technikal Mara (UniKL), and investigates whether the competitiveness of Majlis Amanah Rakyat (MARA) can be explained by its science research capability.

UniKL is a regional leader in engineering technology education. It was established on 20 August 2002 and is owned by MARA, an agency under the Ministry of Rural and Regional Development (KKLW), Malaysia (www.unikl.edu.my). The university is tasked with advancing technical education in Malaysia. UniKL seeks to endow its graduates with solid technological knowledge coupled with business savvy to meet industry demands.

It maintains close links with industry through research development projects and product and research commercialisation (www.unikl.edu.my). The university receives support and funding from the industry in exchange for research and innovation. This dynamic is challenged by the increasing number of universities vying for support from the industry (Ahsan, Abdullah, Fie, \& Alam, 2009; Consilz, 2008). In its pursuit to advance its global ranking, universities in Asia are exploring different strategies to best optimise its resources and realise its potentials (Mok, 2015). In this regard, analysis has revealed that the academic research of Malaysian universities is failing to meet acceptable standards (Shamsul, Rose, \& Azizah, 2008). To improve its global ranking, the Malaysian government has introduced various categories of universities including the status of Research University (RU) and Accelerated Program For Excellence (APEX) university status. It has encouraged the establishment of new private universities and the introduction of foreign universities (Basaruddin, Haron, \& Noodin, 2012; www.waset.org). Such initiatives are in line with its vision 2020 to become a centre for academic excellence (Consilz, 2008; Mohsin \& Kamal, 2012; www.waset.org). Achieving such a goal requires continues evaluation of the current capabilities and performances of Malaysian universities. The current study addresses several aspects regarding this issue.

Based on previously mentioned practical issues (the need to evaluate both the research capabilities and competitiveness of Malaysian Universities) and existing theoretical gaps (the lack of a clear theoretical framework to investigate the link between research capabilities and competitiveness within an educational organisation), this study seeks to answer the following questions:

1. To which extent is UniKL capable to perform useful research?

2. To which extent is UniKL able to compete in the current local market?

3. To what extent can the research capability explain the competitiveness of UNiKL?

\subsection{Research framework and hypotheses}

The study is a theory testing empirical research examining the impacts of research capabilities on competitiveness in UniKL. Based on the relevant literature and resources and knowledge-based theories, the researcher proposes that the research capabilities will work as predictors of the competitiveness, and job satisfaction will mediate this relationship as shown in the following figure:

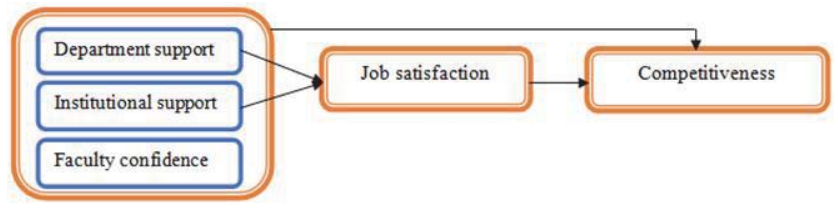

Figure (1): Research Framework 
Barney, Wright, \& Ketchen (2001) articulated that corporations could gain sustained competitive advantage when adopting unique strategies, which are not adopted by other corporations. They added that the corporations' resources become sources of competitive advantage if they achieve the following principles: (1) they are valuable, which means that these resources give the corporation the ability to gain opportunities or avoid threats; (2) they are rare among the market or competitors; (3) they are imperfectly imitable, and (4) they have no strategic equivalent, which indicates that one resource cannot be used as an alternative to another resource. As for research capabilities, it is a source of competitive advantage in view of being tacit knowledge unique to the institution (Audretsch, Hülsbeck, \& Lehmann, 2012; Grant, 1996; Sveiby, 2001; Yang, Lin \& Li, 2010). Accordingly, we state the following propositions:

Proposition1: Research capabilities affect the competitiveness of UniKL.

There are several indicators that management support positively influences job satisfaction (Pineau, Spence, Regan, \& Wong, 2015; Du Preez \& Bendixen, 2015). Additionally, perceptions of organisational support should increase individuals' sense of self-regard and increase the likelihood of employee identification and satisfaction (Edwards \& Peccei, 2015; Ugboro \& Obeng, 2000). Moreover, Babin \& Boles (1996) found job satisfaction can result from employee perceptions of co-worker involvement and supervisory support. The results reveal positive correlation between top management leadership, employee empowerment, job satisfaction, and customer satisfaction. Based on previous literature we conclude that:

Proposition 2: Managerial support affects employees' satisfaction in UniKL

The relationship between employees' attitudes and behaviours and organisational performance has been discussed in many studies (e.g. Barrick, Thurgood, Smith, \& Courtright, 2015; Hijal-Moghrabi, Sabharwal, \& Berman, 2015; Ostroff, 1992; Zutshi \& Sohal, 2004; Vermeeren, Kuipers, \& Steijn, 2014). Zutshi and Sohal (2004) found that involving employees in the planning of the environmental management systems benefitted the corporations in enhancing morale building within the corporation, and fulfilling the customer expectations due to considering employees as stakeholders. This is in line with the argument that employee satisfaction and organisational performance are correlated and a strong relationship is expected between them (Ostroff, 1992). As empirically supported, motivating work design could positively affect organisational performance (Barrick, et al., 2015; Hijal-Moghrabi, et al., 2015). Moreover, Vermeeren et al. (2014) found that job satisfaction positively affects organisational performance. Consequently, the study formed the following hypothesis:

Proposition 3: Employees' satisfaction affect organisational competitiveness of UniKL

This research also seeks to test the mediating effects of job satisfaction on the relationship between research capability and competitiveness by using Baron and Kenny's (1986) model. Job satisfaction serves as a mediator when it is significantly related to each dimension of research capability and competitiveness.

In line with the above conditions, we consider the mediating effects of job satisfaction to be between managerial support and competitiveness. Thus, the last hypothesis is:

Proposition 4: Job satisfaction mediates the relationship between managerial support and competitiveness.

\section{Research methodology}

\subsection{Research Philosophy}

The study adopts a survey questionnaire design for theory testing. The data is collected from a sample of fulltime lecturers in UniKL. The questionnaire is adopted from previous literature to measure the variables of this study. It contains two sections related to the research capability and competitiveness.

\subsection{Instrumentation}

Competitiveness is measured using 31 items adopted from Ronquillo (2012). These items reflect the Porter's Five Competitive Forces Model.

Research capability will be measured using 50 items adopted from Bay and Clerigo (2013). The chosen items measure the three capabilities called institutional and department support, and faculty confidence. The instrument will be tested for its reliability and validity in the pilot study stage.

\subsection{Pilot Study}

Achieving reliability and validity of the questionnaire means that the questions asked are clear to the respondents, and 
the response options are comprehensive and appropriate (Watson, 1998). Such procedures can be achieved by conducting a pilot study. The pilot study is strongly recommended to test the questionnaire (Babbie, 1995; Hair et al., 2007; Watson, 1998). Even though the questionnaire used in this study was adopted from similar previous studies, a pretest of the questionnaire is required. Hair et al. (2007) articulated that:

\section{If a researcher has used a questionnaire in England and is asked to use it in the US it must be pretested. And of course, if the questionnaire were translated into French for use in France it must be extensively pretested (p. 279).}

Hair et al. (2007) suggested that the minimum number for the pre-test should be four or five individuals while the largest number of the pre-test should be no more than 30 . The reliability coefficient scores are considered poor when the Alpha coefficient range $<0.6$, moderate when the range is between 0.6 and 0.7 , good when the range is between 0.7 and 0.8 , very good between 0.8 and 0.9 , and excellent when the Alpha coefficient range equal to or more than 0.9 (Hair et al., 2007; Nunnally, Bernstein, \& Berge, 1967). Alpha $>0.95$ requires checking to certify that they indeed measure the various aspects of the concept (Hair et al., 2007).

After assuring the validity and reliability of the instrumentation, the questionnaires will be distributed to the participants of this study, which are all fulltime lecturers in UniKL. They were chosen because they represent the main persons who engaged in research activities.

\subsection{Sampling}

Collecting the data from multiple respondents is important because it minimizes the potential of bias from a single informant (Delmas, 2001).

Cavana et al. (2001) identified two types of sampling techniques, namely proportionate and disproportionate sampling. By analysing the different approaches, the researcher believes that proportionate stratified sampling was more accurate and promising to reflect the population. This is because the proportionate stratified sampling technique can give equal chances for each institute to be represented by a number of academicians relative to the total population of the institute (Hair et al., 2007). By doing so, the researcher can ensure that all institutions have been represented in the sample.

Choosing the sample of this study depends on the list of all fulltime lecturers (PhD and Master Holders) in the 14 UniKL institutions, which equals 1101. The next section discusses the procedures of determining the sample size.

This study adopted the formula of Dillman (2000) to calculate the sample size:

$\mathrm{n}=\frac{(\mathrm{N})(\mathrm{p})(1-\mathrm{p})}{(\mathrm{N}-1)\left(\frac{\mathrm{B}}{\mathrm{C}}\right)^{2}+(\mathrm{p})(1-\mathrm{p})}$

When

$\mathrm{N}=$ population of the study

$\mathrm{p}=$ the population proportion

$\mathrm{B}=$ the acceptable margin of errors that the researcher is willing to accept for its study

$\mathrm{C}=\mathrm{Z}$ statistic associated with the confidence level.

$\mathrm{n}=$ sample size required at desired level of precision.

$\mathrm{N}=1101, \mathrm{p}$ is assumed to be 0.05 since this would provide the maximum sample size (Krejcie \& Morgan, 1970). Following this, $C$ is considered to be 1.96 because the $Z$ value at confidence level of 0.95 corresponds with 1.96 (Krejcie \& Morgan, 1970). $B=.05$ (meaning the researcher accepted a $5 \%$ margin of error for the study). Consequently, the sample size is calculated as:

$$
\mathrm{n}=\frac{(\mathrm{N})(0.05)(1-0.05)}{(\mathrm{N}-1)\left(\frac{0.05}{1.96}\right)^{2}+(0.05)(1-0.05)}
$$

Additionally, we support our calculations by the sample size table provided by Cavana et al. (2001) and Krejcie \& Morgan (1970). The largest sample will be used following the recommendation that the bigger sample size, the more likely the results are credible and generalizable (Hair et al., 2010; Sekaran).

According to Krejcie \& Morgan (1970), a sample size of $n=285$ can represent a population of 1101 . Therefore, the sample size of this study is 285 .

The total sample size is the total number of fulltime lecturers in UniKL. Therefore, the number of respondents chosen from each institute will be based on the relative frequency of the institute (Size of particular institute relative to the total number of fulltime lecturers in UniKL).

The percentage is calculated as following:

The percentage of each institute $=n / N$ 
$\mathrm{N}=$ Total number of fulltime lecturers in UniKL

$\mathrm{n}=$ Size of particular institute measured by its number of fulltime lecturers

The participants from each institute will be selected randomly using Excel random numbers generation software.

\subsection{Data Analysis}

Prior to testing the main research questions, the data will be detected to ensure its ability to reflect the phenomena under study (data screening). Screening the data considers aspects such as the response rate, non-response bias, and outliers. Ignoring such issues can affect the validity of data and, accordingly, the results of study.

Descriptive statistics will be applied to determine the state of both the research capability and competitiveness, as well as the characteristics of the sample.

Structure Equation Modelling will be used as a group of statistics methods to investigate the relationships among multiple variables, and examine the structure of the interrelationships in a serious of equations (Hair et al., 2010).

\section{Conclusion}

Existing empirical research studying the linkage between research capability and competitiveness have focused on the manufacturing companies (e.g., Dhewanto \& Sohal, 2014; Carneiro, 2000; Guan \& Ma, 2003; Guan, Yam, Mok, \& Ma 2006; Liu, Chen, \& Tsai, 2004). Little attention has been awarded to the service sector, particularly the educational sector (Liu \& Shi, 2008; Siegel, Waldman, Atwater \& Link, 2004). Reviewing the previous literature showed that there is no evidence of research that has investigated the relationship between the research capabilities of universities and multidimensional competitiveness.

Theoretically, this study provides support for both the resource-based view and knowledge-based view theories. Resource-based view has been criticised for its focus on the highly aggregated dependent variable, firm performance (Ray, Barney, \& Muhanna, 2004). Classifying competitiveness into five dimensions according to Porter's Five Competitive Forces Model can shine a light on the importance of disaggregating the dependent variable, instead of using the overall corporate performance. Additionally, Chabowski, Mena, \& Gonzalez-Padron (2011) recommended future studies investigate the internally and externally capabilities-based resources that help the universities in achieving competitiveness. Moreover, the study is an empirical investigation on how universities can improve their competitiveness by creating, extending or modifying its resource base, as suggested by Ambrosini, Bowman, and Collier (2009).

From the practical point of view, the study benefits the decision-makers by highlighting research capability as a predicted tool to improve the competitiveness of the university. By doing so, the study directs the decision-makers to the most appropriate practices for improving both the research capabilities and competitive position.

Finally, methodologically, using the quantitative approach can serve as a base for comparison between the findings of this study and the findings of other studies, which in turn, will enhance the construction validity of the previous studies conducted in different sectors.

\section{References}

Ahsan, N., Abdullah, Z., Fie, D. G., \& Alam, S. S. (2009). A study of job stress on job satisfaction among university staff in Malaysia: Empirical study. European journal of social sciences, 8(1), 121-131.

Ambrosini, V., Bowman, C. \& Collier, N. (2009). 'Dynamic capabilities: An exploration of how firms renew their resource base', British Journal of Management, 20(1), 9-24.

Audretsch, D. B., Hülsbeck, M., \& Lehmann, E. E. (2012). Regional competitiveness, university spillovers, and entrepreneurial activity. Small Business Economics, 39(3), 587-601.

Babbie, E. (1995). The practice of social science research. Belmont, California: Wadsworth.

Babin, B. J., \& Boles, J. S. (1996). The effects of perceived co-worker involvement and supervisor support on service provider role stress, performance and job satisfaction. Journal of retailing, 72(1), 57-75.

Bay Jr, B. E., \& Clerigo, M. E. C. (2013). Factors Associated with Research Productivity among Oral Healthcare Educators in an Asian University. International Education Studies, 6(8), p124.

Baron, R. M., \& Kenny, D. A. (1986). The moderator-mediator variable distinction in social psychological research: Conceptual, strategic, and statistical considerations. Journal of personality and social psychology, 51(6), 1173.

Basaruddin, S., Haron, H., \& Noodin, S. A. (2012). Developing OMS in IHL. Learning, 6(3), 13.

Barrick, M. R., Thurgood, G. R., Smith, T. A., \& Courtright, S. H. (2015). Collective Organisational Engagement: Linking Motivational Antecedents, Strategic Implementation, and Firm Performance. Academy of Management Journal, 58(1), 111-135.

Boccardelli, P \& Magnusson, M. G. (2006) Dynamic capabilities in early-phase entrepreneurship. Knowledge and Process Management, 
13, 162-174.

Barney, J., Wright, M., \& Ketchen, D. (2001). The resource-based view of the firm: Ten years after 1991. Journal of Management, 27 (2001), 625-641.

Carneiro, A. (2000). How does knowledge management influence innovation and competitiveness?. Journal of Knowledge Management, 4(2), 87-98.

Consilz, T. (2008). Teacher-as-Researcher and the Importance towards Malaysia's Education Prospect.

Cavana, R., Delahaye, B. L., \& Sekaran, U. (2001). Applied business research: Qualitative and quantitative methods. Singapore: Markono Print Media Ltd.

Chabowski, B., Mena, J., \& Gonzalez-Padron, T. (2011). The structure of sustainability research in marketing, 1958-2008: A basis for future research opportunities. Journal of Academy of Marketing Science, 39 (2011), 55-70.

Delmas, M. (2001). Stakeholders and competitive advantage: The case of ISO 14001. Production and Operations Management, 10(3), 343-358.

Du Preez, R., \& Bendixen, M. T. (2015). The impact of internal brand management on employee job satisfaction, brand commitment and intention to stay. International Journal of Bank Marketing, 33(1), 78-91.

Duncan, W. J., Ginter, P. M., \& Swayne, L. E. (1998). Competitive advantage and internal organisational assessment. The Academy of Management Executive (1993-2005), 6-16.

Dhewanto, W. \& Sohal, A. S. (2014), The relationship between organisational orientation and research and development/technology commercialisation performance. R\&D Management. doi:10.1111/radm.12073.

Edwards, M. R., \& Peccei, R. (2015). Perceived organisational support, organisational identification, and employee outcomes. Journal of Personnel Psychology.

Giménez, V, M.,\&Martínez, J. L. (2006) Cost efficiency in the university: A departmental evaluation model, [J]. Economics of Education Review, 25, 543-553.

Grant, R. M. (1996). Toward a Knowledge-Based Theory of The Firm. Strategic Management Journal, 17(Winter Special Issue), 109-122

Guan, J., \& Ma, N. (2003). Innovative capability and export performance of Chinese firms. Technovation, 23(9), 737-747.

Guan, J. C., Yam, R. C., Mok, C. K., \& Ma, N. (2006). A study of the relationship between competitiveness and technological innovation capability based on DEA models. European Journal of Operational Research, 17(3), 971-986.

Hart, S. (1995). A natural-resource-based view of the firm. Academy of Mmanagement Review, 20(4), 986-1014.

Hair, J. F., Jr., Black, W. C., Babin, B. J., Andersen, R. E., \& Tatham, R. L. (2010). Mutilvariate data analysis (7th ed.). Upper Saddle River, NJ: Pearson Prentice Hall.

Hair, J. F., Money, A. H., Samouel, P., \& Page, M. (2007). Research methods for business. West Sussex: John Wiley \& Sons Ltd.

Helfat, C, E. \& Peteraf, M, A. (2003). The dynamic resource-based view: Capability lifecycles,[J]. Strategic Management Journal, 24. 997-1010, 2003.

Hijal-Moghrabi, I., Sabharwal, M., \& Berman, E. M. (2015). The Importance of Ethical Environment to Organisational Performance in Employment at Will States. Administration \& Society, 0095399715581043.

Iraldo, F., Testa, F., \& Frey, M. (2009). Is an environmental management system able to influence environmental and competitive performance? The case of the eco-management and audit scheme (EMAS) in the European Union. Journal of Cleaner Production, 17(16), 1444-1452.

Krejcie, R. V., \& Morgan, D. W. (1970). Determining sample size for research activities. Educational and Psychological Measurement, 30 (3), 607-610.

Lankoski, L. (2000). Determinants of environmental profit: An analysis of the firm-level relationship between environmental performance and economic performance. Unpublished PhD Thesis, Helsinki University of Technology, Finland.

Little, T. D., Card, N. A., Bovaird, J. A., Preacher, K. J., \& Crandall, C. S. (2007). Structural equation modeling of mediation and moderation with contextual factors. Modeling contextual effects in longitudinal studies, 207-230. Available at: http://hdl.handle. net/1808/1505

Liu, W., \& Shi, C. (2008). Analysis of University Science Research Capability Elements and Evaluation Based on BP Neural Network. Journal of Service Science and Management, 1(03), 266.

Liu, W. W., \& Shi, C. S. (2009). Dynamic Evaluation of University Science Research Capability Based on Fuzzy Theory. In Fuzzy Information and Engineering Volume 2 (pp. 1569-1577). Springer Berlin Heidelberg.

Liu, W., \& Shi, C. (2008, October). Evaluation for University Scientific Research Capability Based on FCE. In Wireless Communications, Networking and Mobile Computing, 2008. WiCOM'08. 4th International Conference on (pp. 1-4). IEEE.

Liu, P. L., Chen, W. C., \& Tsai, C. H. (2004). An empirical study on the correlation between knowledge management capability and competitiveness in Taiwan'sindustries. Technovation, 24(12), 971-977.

López-Gamero, M., Molina-Azorín, J., \& Claver-Cortés, E. (2009). The whole relationship between environmental variables and firm performance: Competitive advantage and firm resources as mediator variables. Journal of Environmental Management, 90(10), 3110-3121.

Ostroff, C. (1992). The relationship between satisfaction, attitudes, and performance: An organisational level analysis. Journal of applied psychology, $77(6), 963$.

Mok, K. H. (2015). Higher Education Transformations for Global Competitiveness: Policy Responses, Social Consequences and Impact on the Academic Profession in Asia. Higher Education Policy, 28(1), 1-15.

Marcela, S. T. J., \& Carolina, R. T. S. (2011).To Measure Research Capacities of Higher Education Institution in Colombia Using an 
Approach Based on Intellectual Capital.

Mohsin, M., \& Kamal, M. A. (2012). Managing Quality Higher Education in Bangladesh: Lessons from the Singaporean and Malaysian Strategies and Reforms. International Journal of Business and Management, 7(20), 59-70.

McEvily, B., \& Marcus, A. (2005). "Embedded ties and the acquisition of competitive capabilities". Strategic Management Journal, Vol. 26, pp. 1033-1055, 2005.

Noruzi, M. R., \& Vargas-Hernández, J. G. (2010). How intellectual capital and learning organisation can foster organisational competitiveness? International Journal of Business and Management, 5(4), 183-193.

Nunnally, J. C., Bernstein, I. H., \& Berge, J. M. T. (1967). Psychometric theory (Vol. 226). New York: McGraw-Hill.

Pineau Stam, L. M., Spence Laschinger, H. K., Regan, S., \& Wong, C. A. (2015). The influence of personal and workplace resources on new graduate nurses' job satisfaction. Journal of nursing management, 23(2), 190-199.

Porter, M. E. (1985). Competitive strategy: Creating and sustaining superior performance. New York: Free Press.

Porter, M. E., \& Van der Linde, C. (1996). Green and competitive: ending the stalemate. Harvard business review, 73(5), 120-134.

Pickstone, C., Nancarrow, S., Cooke, J., Vernon, W., Mountain, G., Boyce, R. A., \& Campbell, J. (2008). Building research capacity in the allied health professions. Evidence \& Policy: A Journal of Research, Debate and Practice,4(1), 53-68.

Ray, G., Barney, J. B., \& Muhanna, W. A. (2004). Capabilities, business processes, and competitive advantage: Choosing the dependent variable in empirical tests of the resource-based view. Strategic Management Journal, 25(1), 23-37.

Ronquillo, T. A. (2012). Analysis of competitiveness of Batangas State University College of engineering using porter's five competitive forces model. In Profession of Engineering Education: Advancing Teaching, Research and Careers: 23rd Annual Conference of the Australasian Association for Engineering Education 2012, 875-884. Engineers Australia.

Sekaran, U. (2006). Research methods for business: A skill building approach. John Wiley \& Sons.

Sveiby, K. E. (2001). A knowledge-based theory of the firm to guide in strategy formulation. Journal of intellectual capital, 2(4), 344-358.

Swift, T., \& Zadek, S. (2002). Corporate Responsability and the Competitive Advantage of Nations. Copenhagen Centre.

Shamsul, A. M., Rose, A. A., \& Azizah, A., R. (2008). E-research at Malaysian Higher Education Institutions. UniKL Research Journal, 1 (1), 6.

Siegel, D. S., Waldman, D. A., Atwater, L. E., \& Link, A. N. (2004). Toward a model of the effective transfer of scientific knowledge from academicians to practitioners: Qualitative evidence from the commercialization of university technologies. Journal of Engineering and Technology Management, 21(1), 115-142.

Shapira, P., Youtie, J., Yogeesvaran, K., \&Jaafar, Z. (2006). Knowledge economy measurement: Methods, results and insights from the Malaysian Knowledge Content Study. Research Policy, 35(10), 1522-1537.

Teece, D. J (2007). Explicating dynamic capabilities: The nature and micro foundations of (sustainable) enterprise performance. Strategic Management Journal, 28, 1319-1350, 2007.

Vermeeren, B., Kuipers, B., \& Steijn, B. (2014). Does leadership style make a difference? Linking HRM, job satisfaction, and organisational performance. Review of Public Personnel Administration, 34(2), 174-195.

Watson, S. C. (1998). A primer in survey research. Journal of Continuing Higher Education, 46(1), 31-40.

Wernerfelt, B. (1984). A resource-based view of the firm. Strategic Management Journal, 5(2), 171-180.

Wernerfelt, B. (2011). The use of resources in resource acquisition. Journal of Management, 37(5), 1369-1373.

Ugboro, I. O., \& Obeng, K. (2000). Top management leadership, employee empowerment, job satisfaction, and customer satisfaction in TQM organisations: an empirical study. Journal of Quality Management, 5(2), 247-272.

Yang, C. H., Lin, H. L., \& Li, H. Y. (2010). Do R\&D spinoffs have higher R\&D productivity? Evidence from Taiwanese electronics firms. Industry and Innovation, 17(3), 285-307.

Zhu, Q., \& Sarkis, J. (2004). Relationships between operational practices and performance among early adopters of green supply chain management practices in Chinese manufacturing enterprises. Journal of Operations Management, 22(3), 265-289.

www.waset.org

www.unikl.edu.my 